\title{
BRPKM
}
Buletin Riset Psikologi dan Kesehatan Mental http://e-journal.unair.ac.id/index.php/BRPKM e-ISSN: 2776-1851

ARTIKEL PENELITIAN

\section{Peran Ruminasi pada Pengaruh Perfeksionisme terhadap Depresi pada Dewasa Awal}

\author{
PUTU DIDA DIRANA G. \& ENDANG R. SURJANINGRUM* \\ Fakultas Psikologi Universitas Airlangga
}

\begin{abstract}
ABSTRAK
Depresi merupakan gangguan psikologis yang ditandai dengan penyimpangan perasaan, kognitif, dan perilaku individu. Depresi rentan dialami oleh dewasa awal karena berusaha untuk menemukan dan terus menggali minat mereka, ingin menjadi individu seperti apa dan gaya hidup seperti apa yang mereka inginkan ke depannya. Penelitian kuantitatif ini bertujuan untuk mengetahui apakah peran ruminasi pada pengaruh perfeksionisme terhadap depresi pada dewasa awal. Subjek penelitian sebanyak 461 dengan 128 laki-laki dan 333 perempuan yang berusia 18-25 tahun dan pernah mengalami kesedihan terus-menerus selama dua minggu. Penelitian ini menggunakan alat ukur MPS mengukur perfeksionisme, BDI-II mengukur depresi, RRS-Short Form mengukur ruminasi. Analisis data melalui uji regresi linear berganda dan analisis jalur. Dari hasil analisis didapatkan perfeksionisme berpengaruh signifikan terhadap ruminasi pada dewasa awal. Selain itu, didapatkan secara bersamasama perfeksionisme dan ruminasi berpengaruh signifikan terhadap depresi. Dalam hal tersebut ruminasi memediasi penuh pengaruh perfeksionisme terhadap depresi pada dewasa awal.
\end{abstract}

Kata kunci: depresi, perfeksionisme, ruminasi

\begin{abstract}
Depression is a psychological disorder that affects individual feelings, cognitive and behavior. Early adulthood more prone to depression because people are more likely to exploring which career path they want to follow, what they want their identity to be and which lifestyle they want. This quantitative research aims to investigate the role of rumination on the effect of perfectionism to depression on early adulthood. The 461 sample consist of 128 men and 333 women who's 18-25 years old and experience depressed mood. This research used MPS to measure perfectionism, BDI-II to measure depression, RRSShort Form to measure rumination. Data analysis was tested through multiple regression and path analysis. Found that perfectionism has significant effect on rumination on early adulthood. Also found that perfectionism and rumination have significant effect on depression on early adulthood. On that case, rumination fully mediated the effect of perfectionism to depression on early adulthood.
\end{abstract}

Keywords: depression, perfectionism, rumination

Buletin Penelitian Psikologi dan Kesehatan Mental (BRPKM), 2021, Vol. 1(1), 629-637

*Alamat korespondensi: Fakultas Psikologi Universitas Airlangga, Kampus B Universitas Airlangga Jalan Airlangga 4-6 Surabaya 60286. Surel: endang.surjaningrum@psikologi.unair.ac.id

Naskah ini merupakan naskah dengan akses terbuka dibawah ketentuan the Creative Common Attribution License (CC-BY-4.0) (http://creativecommons.org/licenses/by/4.0), 
sehingga penggunaan, distribusi, reproduksi dalam media apapun atas artikel ini tidak dibatasi, selama sumber aslinya disitir dengan baik.

\section{PENDAHULUAN}

Setiap individu umumnya akan mengalami pertumbuhan dan perkembangan. Individu akan mengalami tiga tahapan perkembangan yaitu masa kanak-kanak, masa remaja dan masa dewasa (Santrock, 2013). Transisi tahapan perkembangan dari remaja menuju dewasa disebut sebagai masa dewasa awal (emerging adulthood) saat berusia 18 hingga 25 tahun. Dewasa awal ditandai dengan adanya eksperimen dan eksplorasi (Santrock, 2013). Eksperimen dan eksplorasi yang dimaksud adalah individu berusaha untuk menemukan dan terus menggali minat mereka, ingin menjadi individu seperti apa dan gaya hidup seperti apa yang mereka inginkan ke depannya. Tugas-tugas perkembangan yang harus dilakukan pada masa dewasa awal menurut Havighurst dalam (Hurlock, 1999) antara lain menjalin dan membangun hubungan baru dengan teman sebaya, mencapai peran sosial, mencapai perilaku sosial yang bertanggungjawab, mencapai kemandirian emosional dari orang tua juga lingkungan, mempersiapkan karir ekonomi, mempersiapkan perkawinan, dan kehidupan berkeluarga. Tugas-tugas perkembangan ini menunjukkan banyaknya kemungkinan masalah yang akan dan harus dihadapi oleh individu dewasa awal.

Depresi adalah salah satu gangguan psikologis yang paling umum dialami setiap individu. Depresi merupakan gangguan psikologis yang ditandai dengan penyimpangan perasaan, kognitif, dan perilaku individu (Beck \& Alford, 2009). Angka prevalensi depresi di Indonesia masih tergolong tinggi. Berdasarkan data Riset Kesehatan Dasar Kementerian Kesehatan Republik Indonesia (2018), menunjukkan angka 6,1\% dari kurang lebih 250 juta penduduk Indonesia atau sekitar 15 juta orang di Indonesia mengalami depresi. Berdasarkan data Kementerian Kesehatan Republik Indonesia (2018), dari 15 juta orang di Indonesia yang mengalami depresi tersebut hanya 9\% di antaranya yang berobat ke psikolog atau tenaga medis lainnya. Kementerian Kesehatan Republik Indonesia juga mengeluarkan data prevalensi depresi berdasarkan kelompok usianya. Prevalensi depresi tertinggi dialami oleh individu usia lebih dari 75 tahun dengan prevalensi 8,9\%. Pada urutan keempat kelompok usia 15-24 tahun dengan prevalensi 6,2\% (Kementerian Kesehatan Republik Indonesia, 2020). Usia 15-24 tahun memang menempati urutan keempat prevalensi depresi di Indonesia, namun angka ini masih tergolong tinggi mengingat bahwa Indonesia merupakan negara dengan generasi muda terbesar yaitu kurang lebih 64,50 juta jiwa (Badan Pusat Statistik, 2019).

Depresi muncul akibat dari interaksi kompleks dari faktor sosial, psikologis, dan biologis (WHO, 2020). Individu yang mengalami peristiwa atau pengalaman hidup yang menyakitkan atau menyedihkan akan lebih rentan mengalami depresi. Dalam Bennett (2006) menyebutkan beberapa faktor penyebab depresi yaitu faktor genetis, faktor biologis, faktor sosiokultural, dan faktor kognitif. Beberapa penelitian dilakukan untuk mengembangkan pengetahuan dari faktor-faktor depresi ini. Salah satu faktor yang dapat menjadi penyebab munculnya depresi adalah perfeksionisme. Keinginan individu untuk menjadi sempurna atau perfeksionis meningkat pada 25 tahun terakhir ini (Smith dkk., 2019). Sebuah penelitian menyebutkan bahwa terdapat pengaruh signifikan antara perfeksionisme dengan depresi dan anxiety (Morgan-Lowes dkk., 2019). Penelitian tersebut dilakukan dengan metode kuantitatif pada 167 partisipan yang merupakan remaja perempuan berusia 10-17 tahun. Akademik di dunia Barat sudah sejak lama menyoroti perfeksionisme sebagai suatu konstruk psikologis yang terkait dengan berbagai gejala psikologi negatif (Blatt, 1995). Namun, di Indonesia perfeksionisme masih belum menjadi sorotan serius. Perfeksionisme merupakan sifat kepribadian multidimensional yang

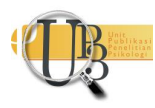


ditandai oleh keinginan kuat untuk mengejar standar kinerja tinggi yang berlebihan dan terlalu kritis pada individu (Hewitt \& Flett, 1991). Salah satu bentuk dari standar tinggi tersebut melibatkan persepsi tentang kebutuhan yang harus memenuhi standar yang dipaksakan oleh orang lain memiliki kaitan dengan depresi. Smith dkk. (2019) menyebutkan bahwa perfeksionisme dapat mengarah pada beberapa masalah kesehatan mental salah satunya adalah depresi. Perfeksionisme terkait dengan munculnya gejala depresi karena individu dengan kepribadian ini mengalami stres dan keputusasaan sosial akibat tidak mampu mengendalikan atau memenuhi harapannya atau orang lain pada dirinya, (Blatt, 1995). Individu yang cenderung memikirkan kecemasan akan kegagalan memenuhi standar tersebut dapat dikatakan sebagai perfeksionisme maladaptif. Sementara itu terdapat pula pola perfeksionisme adaptif. Perfeksionisme adaptif terkait pada gairah untuk mencapai yang terbaik pada standar yang telah ditetapkan oleh individu itu sendiri ataupun oleh orang lain tanpa memikirkan kecemasan akan kegagalan yang nantinya terjadi.

Melihat bagaimana keterkaitawrn dari perfeksionisme dan depresi, pemikiran kecemasan akan kegagalan tidak terpenuhinya standar yang tinggi menuntun kita untuk melihat bagaimana peran mekanisme kognitif di dalamnya. Salah satu mekanisme kognitif yaitu ruminasi dapat menjadi mediasi dari munculnya depresi dan terkait dengan perfeksionisme. Ruminasi menurut Miranda \& NolenHoeksema (2007) adalah sejauh mana individu secara berulang fokus pada penyebab, makna, dan konsekuensi dari suasana hati yang negatif. Ruminasi dapat mengarah pada pemecahan masalah dan dapat juga tidak mengarah pada pemecahan masalah melainkan mengarah pada munculnya depresi. Ruminasi dapat memediasi hubungan antara maladaptif perfeksionis dengan symptom depresi (Harris dkk., 2008). Temuan tersebut juga ditegaskan oleh Di Schiena dkk (2012) menyatakan bahwa salah satu tipe ruminasi yaitu abstrac-analytic (AA) memediasi antara maladaptif perfeksionisme dan perkembangan sindrom depresi. Ruminasi dapat memediasi munculnya depresi dikarenakan individu yang terus menerus memikirkan perasaan negatif dari peristiwa yang ia hadapi sebelumnya dapat mengganggu fungsi kognitif normalnya dan menghambat penyelesaian masalah yang seharusnya dilakukan.

Secara khusus, apabila kita melihat keterkaitan antara ruminasi dan perfeksionisme ini juga dapat kita lihat pada penelitian yang dilakukan oleh Di Schiena dkk (2012) dalam model regresi yang dilakukan pada maladaptif perfeksionisme dan ruminasi memiliki pengaruh positif dan signifikan. Hal ini dapat terjadi karena individu dengan perfeksionisme maladaptif memiliki pemikiran tentang ketakutan mereka tidak mampu mencapai standarnya (Di Schiena dkk. 2012). Selain itu, apabila melihat secara khusus keterkaitan antara ruminasi dan depresi, kita dapat mengacu pada penelitian yang dilakukan oleh Whisman dkk. (2020) yang menemukan bahwa ruminasi bisa menjadi faktor risiko potensial dan faktor konsekuensi dari munculnya simptom depresi pada orang dewasa. Keterkaitan antara ruminasi dan depresi juga dapat dilihat dari pola kognitif depresi dengan empat konstruknya yaitu schemata, cognitive errors, cognitive triad, dan automatic thoughts. Winkeljohn Black \& Pössel (2015) menyebutkan bahwa schemata mempengaruhi munculnya ruminasi, kemudian ruminasi mempengaruhi munculnya tiga konstruk kognitif depresi lainnya. Apabila dikaitkan dengan teori kognitif, menyebutkan bahwa individu dengan maladaptif perfeksionisme setelah satu tahun dapat menyebabkan munculnya distorsi kognitif (Macedo dkk., 2017). Distorsi kognitif yang dimaksudkan dapat berupa catastrophize yaitu kegagalan berpikir secara logis dan cenderung melebih-lebihkan pemikiran negatif. Apabila individu dengan maladaptif perfeksionisme tersebut mengalami distorsi kognitif diiringi dengan merenungkan pikiran dan perasaan mereka (atau dapat dikatakan mengalami ruminasi) terkait dengan peristiwa negatif yang mereka alami maka dapat menimbulkan depresi (Macedo dkk., 2017). 
Berdasarkan pemaparan di atas, penulis tertarik untuk mengetahui apakah terdapat pengaruh perfeksionisme dengan terhadap depresi dengan ruminasi sebagai mediator pada kelompok usia dewasa awal. Pertanyaan inilah yang akan dicoba dijawab dalam penelitian ini. Adapun hipotesis dalam penelitian ini antara lain: perfeksionisme memiliki pengaruh terhadap ruminasi, perfeksionisme dan ruminasi memiliki pengaruh terhadap depresi, serta ruminasi memediasi pengaruh perfeksionisme terhadap depresi. Penelitian ini bertujuan untuk menguji secara empiris dan mengetahui apakah peran ruminasi pada pengaruh perfeksionisme terhadap depresi pada dewasa awal.

\section{Desain Penelitian}

\section{METODE}

Penelitian ini merupakan penelitian kuantitatif-eksplanatori dengan metode pengambilan data menggunakan survei yang disampaikan kepada partisipan yang memenuhi kriteria.

\section{Partisipan}

Teknik sampling yang digunakan dalam penelitian ini adalah teknik non-probability sampling dengan tipe purposive sampling. Sebelum melakukan pengambilan data, peneliti menggunakan bantuan program $\mathrm{G}^{*}$ Power dalam menentukan jumlah sampel. Penentuan jumlah sampel menggunakan a priori: Compute required sample size yang menghasilkan ukuran efek (Cohen $\mathrm{f}^{2}$ ) sebesar 0,15, nilai < 0,05, dan power (1- $\beta$ ) sebesar 0,95 pada jumlah prediktor yaitu 2 . Hasil dari penghitungan menyatakan bahwa sampel yang dibutuhkan sebanyak 107 sampel.

Partisipan dalam penelitian ini adalah laki-laki atau perempuan yang berusia 18-25 tahun dan pernah mengalami kesedihan terus-menerus selama kurang lebih dua minggu yang dibuktikan melalui alat ukur depresi. Partisipan dalam penelitian ini diberikan informed consent terlebih dahulu sebelum mengisi kuesioner. Sebanyak 461 orang ikut berpartisipasi partisipan $\left(M_{\text {usia }}=21,03 ; S D_{\text {usia }}=1,468 ; 72,7\right.$ persen perempuan).

\section{Pengukuran}

Pengukuran dalam penelitian ini menggunakan tiga alat ukur yaitu Multidimensional Perfectionism Scale (MPS) oleh Hewitt \& Flett (1991) untuk mengukur variabel x perfeksionisme yang terdiri dari 45 aitem. MPS menggunakan skala likert dengan rentang 1 (sangat tidak setuju) sampai 7 (sangat setuju), dengan koefisien reliabilitas yang cukup baik $(\langle=0,830)$. Beck Depression Inventory II (BDI II) oleh Beck (1996) untuk mengukur variabel y depresi yang terdiri dari 21 aitem. BDI-II menggunakan skala likert dengan rentang 0 sampai 3, dengan koefisien reliabilitas cukup baik $(\langle=0,905)$. Ruminative Responses Scale-Short Form (RRS) yang disusun oleh Nolen-Hoeksema (1991) untuk mengukur variabel z ruminasi dengan 10 aitem. RRS-Short Form menggunakan skala likert dengan rentang 1 (hampir tidak pernah) sampai 4 (selalu), dengan koefisien reliabilitas cukup baik $(\langle=0,664)$. Normal apabila dalam skala short form reliabilitas berada di 0,5 (Pallant, 2011). Skala ruminasi ini dapat dikatakan reliabel karena skala yang digunakan adalah skala short form dengan 10 aitem. Seluruh skala disampaikan kepada partisipan melalui google forms yang disebarkan secara online.

Sebelum melakukan uji regresi dan analisis jalur, dilakukan uji asumsi. Hasil uji asumsi menunjukkan data berdistribusi normal, tidak menunjukkan gejala heterokedastisitas, tidak terdapat multikolinearitas, serta terdapat hubungan yang linear dari masing-masing variabel. 


\section{Analisis Data}

Pembuktian hipotesis dilakukan melalui uji regresi dan analisis jalur dengan bantuan software IBM SPSS Statistic 22.00 for Mac. Uji regresi dilakukan untuk mengetahui pengaruh variabel bebas terhadap variabel terikat. Analisis jalur dilakukan untuk melihat apa peran variabel mediasi dalam penelitian ini.

\section{HASIL PENELITIAN}

Hasil analisis data menunjukkan bahwa setelah dilakukan uji regresi linear sederhana, model regresi perfeksionisme dan ruminasi memiliki pengaruh yang signifikan $\left(F(1,459)=34,443 ; p=0 ; R^{2}=0,070\right)$. Dari model regresi tersebut, variabel prediktor menjelaskan sebesar $7 \%$ variabel dependen. Ruminasi berkorelasi positif dan signifikan menjelaskan perfeksionisme $(B=0,49 ; S E=0,008 ; P=0,00)$.

Analisis data uji regresi linear berganda menunjukkan bahwa model regresi perfeksionisme dan ruminasi memiliki pengaruh yang signifikan pada depresi $\left(F(2,459)=44,433 ; R^{2}=0,163\right)$. Dari model regresi tersebut, secara simultan kedua variabel prediktor menjelaskan sebesar 16,3\% variabel dependen. Perfeksionisme memiliki pengaruh positif yang tidak signifikan pada depresi $(B=0,031$; $S E=0,021 ; P=0,144)$. Sementara itu ruminasi memiliki pengaruh positif yang signifikan pada depresi $(B=0,973 ; S E=0,113 ; P=0,00)$.

Untuk mengetahui peran mediasi dari ruminasi pada model regresi perfeksionisme pada depresi, maka dilakukan analisis jalur. Pada hasil analisis jalur a yaitu perfeksionisme berpengaruh signifikan pada ruminasi $(B=0,49 ; S E=0,008 ; P=0,00)$. Anlisis jalur b yaitu ruminasi berpengaruh signifikan pada depresi $(B=0,973 ; S E=0,113 ; P=0,00)$. Analisis jalur $\mathrm{c}$, efek langsung perfeksionisme berpengaruh signifikan pada depresi $(B=0,079 ; S E=0,22 ; P=0,00)$. Analisi jalur $c^{\prime}$, efek tidak langsung perfeksionisme pada depresi dengan ruminasi tidak berpengaruh signifikan $(B=0,031 ; S E=0,021 ; P=1,44)$.

\section{DISKUSI}

Penelitian ini bertujuan untuk melihat apa peran ruminasi pada pengaruh perfeksionisme terhadap depresi pada dewasa awal. Usia dewasa awal merupakan kelompok usia yang rentan mengalami depresi. Hal ini dapat disebabkan oleh individu pada masa dewasa awal akan berusaha untuk mencari dan menemukan kemungkinan-kemungkinan hidup yang akan terjadi dengan berbagai macam pilihan dan tantangan. Dalam melaksanakan tugas-tugas perkembangan pada masa dewasa awal seperti membangun hubungan baru dengan teman sebaya, mencapai peran sosial, mencapai perilaku yang bertanggungjawab, mencapai kemandirian emosional, mempersiapkan karir, ekonomi, dan kehidupan berkeluarga memerlukan waktu dan usaha yang tidak mudah. Oleh karena itu, usia dewasa awal merupakan salah satu kelompok usia yang rentan mengalami depresi. Salah satu contoh dimana tugas perkembangan dewasa awal yang cukup kompleks ini memiliki potensi masalah sehingga dapat memunculkan gejala depresi adalah pada tugas perekembangan mempersiapkan karir ekonomi (Santrock, 2013). Indivdiu dewasa awal yang sudah bekerja biasanya menghabiskan sebagian besar waktunya di lingkungan kerja, dengan beban tugas yang banyak individu dapat mengalami depresi (Santrock, 2013). Sebaliknya apabila individu dewasa awal ini masih belum menemukan karir pekerjaan mereka, dapat menjadi penyebab munculnya emotional distress dan kepercayaan diri yang rendah (Santrock, 2013). 
Hasil analisis menemukan adanya pengaruh perfeksionisme terhadap ruminasi. Temuan ini sejalan dengan penelitian yang dilakukan oleh Harris dkk. (2008) dan Di Schiena dkk. (2012). Mereka melakukan model regresi terhadap perfeksionisme pada ruminasi. Dalam penelitian tersebut ditemukan bahwa perfeksionisme maladaptif memilki pengaruh positif yang signifikan terhadap ruminasi (Harris dkk., 2008; Di Schiena dkk., 2012) . Lebih lanjut ditegaskan bahwa individu dengan perfeksionisme yang adaptif tidak memiliki keterkaitan pada munculnya ruminasi (Di Schiena dkk., 2012). Perfeksionisme dapat menjadi suatu konstruk yang adaptif juga maladaptif. Perfeksionisme adaptif terkait pada gairah untuk mencapai yang terbaik dengan standar yang telah ditetapkan baik oleh individu itu sendiri ataupun oleh orang lain tanpa memikirkan kecemasan akan kegagalan yang nantinya terjadi. Perfeksionisme maladaptif berlawanan dengan perfeksionisme adaptif. Perfeksionisme maladaptif memandang kegagalan sebagai suatu ancaman. Maka dari itu, individu dengan perfeksionisme maladaptif cenderung untuk memikirkan dan merenungkan atau dengan kata lain melakukan ruminasi tentang ancaman yang akan terjadi apabila mereka tidak mampu mencapai standar tinggi tersebut.

Secara simultan atau bersama-sama perfeksionisme dan ruminasi berpengaruh signifikan pada munculnya depresi. Penemuan yang sama juga ditemukan dalam studi yang dilakukan oleh (Olson \& Kwon, 2008) yaitu terdapat peningkatan munculnya depresi yang diakibatkan oleh adanya perfeksionisme dan ruminasi serta stress grup yang tinggi. Penelitian tersebut menyatakan bahwa kemunculan depresi pada individu disebabkan oleh adanya standar terhadap kemampuan dan keberhasilan individu yang tinggi serta individu yang sering memikirkan dan merenungkan tentang bagaimana mereka dapat mencapai standar yang tinggi tersebut (Olson \& Kwon, 2008). Penelitian yang dilakukan oleh (Senra dkk., 2018) menemukan bahwa individu dengan standar perfeksionisme yang tinggi serta tendensi yang kuat untuk merefleksikan makna umum dan implikasi dari suatu peristiwa yang buruk atau disebut sebagai ruminasi maladaptif mengarah pada munculnya gejala depresi. Sementara itu individu yang berfokus pada hal-hal yang lebih spesifik dan kontekstual terhadap pengalaman diri yang dialami atau disebut ruminasi adaptif tidak mengarah pada munculnya depresi. Apabila dikaitkan dengan faktor kognitif penyebab depresi maka hal ini menunjukkan adanya salah satu penyimpangan kognitif pada individu depresi berupa overgeneralization, dimana individu hanya menarik kesimpulan umum berdasarkan pada satu peristiwa tunggal saja dan absolutic thinking, yaitu individu berpikir dan berfokus hanya pada 'semua atau tidak sama sekali' serta selective abstraction yaitu individu hanya mengambil kesimpulan dari satu konteks tanpa melihat konteks lainnya (Bennett, 2006).

Penelitian ini juga menguji apakah efek mediasi dari ruminasi tersebut pada pengaruh perfeksionisme yang tinggi dan munculnya gejala depresi. Berdasarkan hasil penelitian ini ditemukan bahwa terdapat peran ruminasi memediasi penuh pengaruh perfeksionisme pada munculnya depresi. Hal ini menjawab hipotesis kerja dua dari penelitian ini. Efek dari pengaruh perfeksionisme pada depresi menurun dan tidak lagi signifikan ketika ruminasi diikut sertakan mengontrol depresi. Perfeksionisme mempengaruhi munculnya ruminasi yang kemudian ruminasi mempengaruhi munculnya depresi. Hal ini terjadi karena terkait dengan perfeksionisme maladaptif dimana individu memandang kegagalan sebagai suatu ancaman. Individu terus memikirkan tentang bagaimana mereka gagal mencapai standar, atau yang disebut sebagai ruminasi. Maka individu yang perfeksionis dan mengalami depresi dijelaskan dari ruminasi yang dilakukannya. Temuan dalam penelitian ini sejalan dengan penelitian sebelumnya yang dilakukan oleh Di Schiena dkk (2012) yang menguji model mediasi yang mengarah pada pengaruh perfeksionisme maladaptif terhadap munculnya depresi. Apabila dikaitkan dengan mekanisme HEXAGON dalam ruminasi, individu dengan perfeksionisme tinggi yang haus akan kesempurnaan 
tersebut melakukan pola pikir abstrak terhadap peristiwa yang terjadi dan akan membentuk bias negatif (Watkins \& Roberts, 2020).

\section{SIMPULAN}

Penelitian ini menyimpulkan pengaruh perfeksionisme terhadap terjadinya ruminasi, yang secara bersama-sama keduanya mempengaruhi munculnya depresi. Individu dengan perfeksionisme yang maladaptif terus berusaha untuk mengerjakan setiap hal sesuai dengan standar tinggi yang telah ditetapkan dan ini dapat memicu munculnya ancaman dan pemikiran berlebihan ketika tidak mampu memenuhi standar tersebut. Akibatnya individu mulai merenungkan perasaan mereka, kesalahan yang terjadi, dan peristiwa yang menjadi penyebab kesalahan tersebut, secara terus-menerus hingga berujung pada munculnya depresi.

Penelitian terhadap kelompok depresi klinis perlu dilakukan untuk menguatkan simpulan atas pengaruh perfeksionisme dan ruminasi pada depresi.

\section{UCAPAN TERIMAKASIH}

Penulis memanjatkan syukur pada Tuhan Yang Maha Esa. Penulis juga mengucapkan terima kasih pada keluarga, teman-teman, dan seluruh pihak atas dukungan semangat dan bantuannya dalam proses penelitian ini.

\section{DEKLARASI POTENSI TERJADINYA KONFLIK KEPENTINGAN}

Putu Dida Dirana Grudug dan Endang R. Surjaningrum tidak bekerja, menjadi konsultan, memiliki saham, atau menerima dana dari perusahaan atau organisasi manapun yang mungkin akan mengambil untung dari diterbitkannya naskah ini.

\section{PUSTAKA ACUAN}

Badan Pusat Statistik. (2019). Statistik Pemuda Indonesia 2019. Badan Pusat Statistik.

Beck, A. T. (1996). BDI-II Beck Depression Inventory.

Beck, A. T., \& Alford, B. A. (2009). Depression, Causes and Treatment. In Depression, Second Edition. https://doi.org/10.4324/9781315824338

Bennett, P. (2006). Abnormal and Clinical Psychology: An Introductory Textbook.

Blatt, S. J. (1995). The destructiveness of perfectionism: Implications for the treatment of depression. American Psychologist, 50(12), 1003-1020. https://doi.org/10.1037/0003-066X.50.12.1003

Di Schiena, R., Luminet, O., Philippot, P., \& Douilliez, C. (2012). Adaptive and maladaptive perfectionism in depression: Preliminary evidence on the role of adaptive and maladaptive rumination. $\begin{array}{lllll}\text { Personality and } & \text { Individual }\end{array}$ https://doi.org/10.1016/j.paid.2012.05.017

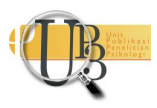


Harris, P. W., Pepper, C. M., \& Maack, D. J. (2008). The relationship between maladaptive perfectionism and depressive symptoms: The mediating role of rumination. Personality and Individual Differences, 44(1), 150-160. https://doi.org/10.1016/j.paid.2007.07.011

Hewitt, P. L., \& Flett, G. L. (1991). Perfectionism in the Self and Social Contexts: Conceptualization, Assessment, and Association With Psychopathology. Journal of Personality and Social Psychology, 60(3), 456-470. https://doi.org/10.1037/0022-3514.60.3.456

Hurlock, E. B. (1999). Perkembangan Anak. Penerbit Erlangga.

Kementerian Kesehatan Republik Indonesia. (2018). Riset Kesehatan Dasar 2018. Badan Penelitian dan Pengembangan Kemenkes.

Kementerian Kesehatan Republik Indonesia. (2020). Infodatin Situasi Situasi Kesehatan Jiwa di Indonesia. Pusat Data dan Informasi Kemenkes.

Macedo, A., Marques, C., Quaresma, V., Soares, M. J., Amaral, A. P., Araújo, A. I., \& Pereira, A. T. (2017). Are perfectionism cognitions and cognitive emotion regulation strategies mediators between perfectionism and psychological distress? Personality and Individual Differences, 119, 46-51. https://doi.org/10.1016/j.paid.2017.06.032

Miranda, R., \& Nolen-Hoeksema, S. (2007). Brooding and reflection: Rumination predicts suicidal ideation at 1-year follow-up in a community sample. Behaviour Research and Therapy, 45(12), 3088-3095. https://doi.org/10.1016/j.brat.2007.07.015

Morgan-Lowes, K. L., Clarke, P. J. F., Hoiles, K. J., Shu, C. Y., Watson, H. J., Dunlop, P. D., \& Egan, S. J. (2019). The relationships between perfectionism, anxiety and depression across time in paediatric eating disorders. Eating Behaviors, 34(June). https://doi.org/10.1016/j.eatbeh.2019.101305

Nolen-Hoeksema, S. (1991). Responses to Depression and Their Effects on the Duration of Depressive Episodes. Journal of Abnormal Psychology, 100(4), 569-582. https://doi.org/10.1037/0021843X.100.4.569

Olson, M. L., \& Kwon, P. (2008). Brooding perfectionism: Refining the roles of rumination and perfectionism in the etiology of depression. Cognitive Therapy and Research, 32(6), 788-802. https://doi.org/10.1007/s10608-007-9173-7

Pallant, J. (2011). SPSS Survival Manual website. 359.

Santrock, J. W. (2013). Life-Span Development.pdf (p. 644).

Senra, C., Merino, H., \& Ferreiro, F. (2018). Exploring the link between perfectionism and depressive symptoms: Contribution of rumination and defense styles. Journal of Clinical Psychology, 74(6), 1053-1066. https://doi.org/10.1002/jclp.22571

Smith, M. M., Sherry, S. B., Vidovic, V., Saklofske, D. H., Stoeber, J., \& Benoit, A. (2019). Perfectionism and the Five-Factor Model of Personality: A Meta-Analytic Review. Personality and Social Psychology Review, 23(4), 367-390. https://doi.org/10.1177/1088868318814973 
Watkins, E. R., \& Roberts, H. (2020). Reflecting on rumination: Consequences, causes, mechanisms and treatment of rumination. Behaviour Research and Therapy, 127(November 2019). https://doi.org/10.1016/j.brat.2020.103573

Whisman, M. A., du Pont, A., \& Butterworth, P. (2020). Longitudinal associations between rumination and depressive symptoms in a probability sample of adults. Journal of Affective Disorders, 260(May), 680-686. https://doi.org/10.1016/j.jad.2019.09.035

WHO. (2020). Mental Health: Depression. https://www.who.int/news-room/factsheets/detail/depression \%0D

Winkeljohn Black, S., \& Pössel, P. (2015). Integrating Beck's Cognitive Model and the Response Style Theory in an Adolescent Sample. Journal of Youth and Adolescence, 44(1), 195-210. https://doi.org/10.1007/s10964-013-0087-2 